\title{
Effect of Humic and Fulvic Acids Mixture Treatment on Productive and Reproductive Performance of Damascus Goat Bucks: \\ 1. Thermoregulation, Body Weight, Sexual Desire and Semen Quality under Heat Stress Condition

\author{
Abdel-Khalek, A. E. ${ }^{1}$; E. S. El-Gohary ${ }^{2}$; Sh. A. Gabr ${ }^{3}$; M. E. Hamad ${ }^{3}$ and N. B. Abdul Jabbar ${ }^{3}$ \\ ${ }^{1}$ Animal Production Department, Faculty of Agriculture, Mansoura University, \\ ${ }^{2}$ Animal Production Research Institute, Agricultural Research Center, Egypt. \\ ${ }^{3}$ Tanta University, Egypt.
}

\begin{abstract}
The objective of this study was to determine effect of humates, HTs (humic and fulvic acid mixture) on thermoregulation, body weight, sexual desire and semen quality of Damascus goat bucks under summer hot condition. The experimental work of this study was carried out at Sheep and Goats Breeding Research Department, Animal Production Research Institute. The experimental period lasted for 5 months, two months as primary period (April-May) and three months (Jun-August, 2017) as a semen collection period. During an experimental period of $5 \mathrm{mo}$, fifteen Damascus goat bucks weighing 31-33 $\mathrm{kg}$ and with 14-15 mo old were divided to three groups ( $\mathrm{n}=5$ ). Bucks of the $1^{\text {st }}$ group (G1) had no treatment (control), but bucks in the second and third groups were daily administrated orally with 50 mg HTs (G2) and $100 \mathrm{mg}$ HTs (G3) per kg live body weight of buck, respectively. The determined amount of humic and fulvic acids mixture in powder form was mixed with distilled water in an emulsion dose of $5 \mathrm{ml} /$ buck during treatment period. Throughout the experimental period, ambient temperature (AT) and relative humidity (RH \%) were recorded weekly and the physiological measurements were determined (13:00-14:00 h) and temperature-humidity index (THI) was estimated. All bucks were fed the same ration (concentrate feed mixture, berseem hay and rice straw and kept under the same housing and managerial conditions. Hair (HT), skin (ST), rectal (RT), scrotal (SCT) and ear (ET) temperature degrees, respiration (RR) and pulse (PR) rates were determined. Live body weight of bucks (LBW) was determined during the experimental period. Body measurements (length, depth and chest circumference), and ear length were determined pre-treatment (initial) and at the end of experiment (final). Scrotal circumference (SC) and testicular length (TL) and volume (TV) were measured. Reaction time was determined and semen was collected by artificial vagina. Results indicated that bucks in all groups exposed to very severe heat stress during the experimental months from Jun to August. Both RT and SCT reduced (P<0.05) in G2 and G3, while RR and PR decreased $(\mathrm{P}<0.05)$ in G3 only. However, the effect of HTs on HT, ST, ET, internal gradients between RT-ST, ST-HT, RT-SCT and ST-SCT was not significant. External gradient between each of HT, ET and RT, and AT was lower (P<0.05) in G2 and G3 than in G1, but gradient between ST-AT was not affected by HTs treatment. Slight differences between groups in buck weights from April up to $1^{\text {st }}$ Jun, then bucks in G2 were heavier $(\mathrm{P}<0.05)$ than in G1 and G2 during July and August. The effect of HTs treatment on body measurements, TV and SC was not significant. Allici treatment increased $(\mathrm{P}<0.05)$ testicular length and plasma testosterone concentration, while decreased $(\mathrm{P}<0.05)$ reaction time as compared to control. Treatment with HTs improved $(\mathrm{P}<0.05)$ all physical semen characteristic and sperm outputs in G2 and G3 compared with G1. In conclusion, bucks in G3 receiving orally dose of 100 mg humic and fulvic acids mixture/kg LBW in hot months of summer season showed highest thermal regulation, which maintain live body weight, improve sexual desire and semen quality under heat stress condition.
\end{abstract}

Keywords: Goat, humates, hot, body temperature, libido, semen.

\section{INTRODUCTION}

Recognition of the reproductive characteristics of small ruminants is an essential starting point towards improving its productivity. The reduction in male numbers used for breeding is considered as one of the most immediate benefits of artificial insemination (AI). There is a tendency to focus more on the female side with much less emphasis on the male side, whereas male fertility is important than female fertility (Davidson and Farver, 1980; Syrstad, 1981). In sheep, maintaining fertile rams with good quality semen is important for improving overall fertility of sheep flock (Rege et al., 2000). More ewes per ram can be employed; conception rates would increase by using fertile rams (Gherardi et al., 1980).

The humates (HTs) are geological deposits in the earth's surface composed mainly of decaying matter of plants and animals through the biological activities of microorganisms. The HTs are naturally occurring substances that include various biologically active and inactive compounds. Based on solubility in acids and bases and by molecular weight, HTs can be categorized into fulvic acid (FA), humic acid (HA) and humin. The main extractable components of HTs are HA. The HTs are composed of many functional groups $(\mathrm{COOH}, \mathrm{OH}, \mathrm{C}=\mathrm{O})$ and become more oxidized over periods of time, which decreases solubility due to the decrease in bound oxygen (Stevenson 1982).

The use of HTs (HA/FA acid) as a feed supplement (growth promoter) is an increasing interest among scientists and the agricultural industry. Including HTs in poultry diets leads to an increase feed efficiency, growth and productivity, and a decrease in illness (Kocabagli et al., 2002; Karaoglu et al., 2004). In this context, dietary HTs supplementation at different levels improved live body weight in broilers (Taklimi et al., 2012) and turkey (Mirnawati and Marida, 2013) as well as increasing egg production, feed conversion and viability of laying hens (Hayirlı et al., 2005).

In ruminants, the use of $\mathrm{HA}$ to minimize $\mathrm{NH}_{3}$ emissions from beef cattle feedlots was evaluated by Shi et al. (2001). They concluded that brown and black HTs in vitro reduced cumulative $\mathrm{NH}_{3}$ emissions by 67.6 and $60.2 \%$, respectively. These N-binding amounts could prove to be beneficial in the retention of NH3-N in the rumen. Chirase et al. (2000) showed no adversely impact of HTs addition on dry matter intake, daily gain, feed conversion ratio, feed palatability or liver function of beef steers. The HTs cause the immune system to recognize its own dead cells thereby reducing infection. Sodium humate has been found to increase the lifespan of mongrel rats exposed to lethal doses of cobalt radiation (Pukhova et al., 1987). 
There are many factors influencing the quality and quantity of goat semen such as breed, age, season, photoperiod, nutrition and collection rhythms. There has been minimal research on the utilization of HTs in goat diets and their effect on semen quality under heat stress condition. Therefore, our objective was to determine the effects of humates on reproductive performance of goat bucks during different seasons of the year.

\section{MATERIALS AND METHODS}

The present study was carried out at Department of Animal Production, Faculty of Agriculture, Tanta University in cooperation with Sheep and Goats Breeding Research Department, Animal Production Research Institute, Ministry of Agriculture, Egypt. The experimental period lasted for 2 months as treatment period (April-May) and three months (July-August, 2017) as a semen collection period.

\section{Animals and treatment:}

A total of fifteen Damascus goat bucks weighing 31-33 kg and aging 14-15 mo were divided into 3 experimental groups $(n=5)$. During an experimental period of 5 months, no treatment was reported for bucks (G1, control). Bucks in G2 and G3 were daily administrated with oral dose of humates (humic and fulvic acid) at levels of 50 and $100 \mathrm{mg} / 1 \mathrm{~kg}$ live body weight of buck, respectively. The determined amount of humic and fulvic acids mixture in powder form was mixed with distilled water in an emulsion dose of $5 \mathrm{ml} /$ buck and administrated orally for two months (April-May) as treatment period and 3 months (Jun-August) as a period of semen collection.

\section{Housing and climatic condition:}

During the experimental period, the experimental groups, bucks were housed in semi-open sheds. Both air temperature (AT) degree, relative humidity ( $\mathrm{RH} \%$ ) and physiological response measurements were recorded weekly at 13:00-14:00 h. Ambient air temperature was recorded using digital thermometer, while $\mathrm{RH}$ was recorded using hair-hygrometer.

Index of temperature-humidity (THI) was calculated according to equation of Livestock Poultry Heat Stress Index (1990) and modified by Marai et al. (2000) as follows:

$$
\mathrm{THI}=\mathrm{dbT}-[(\mathbf{0 . 3 1}-0.31 \mathrm{RH})(\mathrm{dbT}-14.4)]
$$

Where: $d b T=$ dry bulb temperature in Celsius $\left({ }^{\circ} \mathrm{C}\right)$ and $\mathrm{RH}=$ relative humidity/100. The obtained values of THI were classified as absence of heat stress $(\leq 22.2)$, moderate heat stress $(>22.2-\leq 23.3)$, severe heat stress $(>23.3-\leq 25.6)$ and very severe heat stress $(>25.6)$.

\section{Feeding system:}

During the experimental period, bucks were fed in group on concentrate feed mixture (CFM), berseem hay and rice straw according to sheep requirements of NRC (1985). The CFM composed of wheat bran (37.4\%), yellow corn $(27 \%)$, soybean meal $(12.5 \%)$, decorticated cottonseed cake $(10.0 \%)$, rice bran $(5 \%)$, sugarcane molasses (4\%), limestone (3\%), sodium chloride (1\%) and vitamin and minerals premix $(0.1 \%)$. The CFM and hay were offered twice/day ( 8 a.m. and 4 p.m.), while rice straw, fresh drinking water and block minerals were available all time for all groups.
Chemical analysis of different feeds was carried out after the methods of A.O.A.C. (2000) is presented in Table 1, Meanwhile composition of humates according to Humate lab data of the same product is shown in Table 2.

Table 1. Chemical composition concentrate feed mixture, rice straw, berseem hay and humic and fulvic acidsmixture.

\begin{tabular}{lccccccc}
\hline \multirow{2}{*}{ Feed stuff } & \multirow{2}{*}{\begin{tabular}{c} 
DM \\
\cline { 3 - 8 }
\end{tabular}} & \multicolumn{6}{c}{ Chemical analysis (\%) on DM basis } \\
\cline { 2 - 8 } Concentrate & 89.10 & 88.46 & 14.46 & 12.40 & 3.11 & 58.49 & 11.36 \\
feed mixture & & & & & & & \\
Rice straw & 88.46 & 79.60 & 3.50 & 35.10 & 1.40 & 39.60 & 20.4 \\
Berseem hay & 89.74 & 89.59 & 10.64 & 38.54 & 1.03 & 39.38 & 10.41 \\
Humic and & 91.4 & - & 7.10 & 12.5 & - & 51.2 & 8.33 \\
fulvic acid* & & - & &
\end{tabular}

* Humic Acid 42 to $48 \%$ Fulvic Acid 12\% of Humic acid values.

Table 2. Mineral content in humic and fulvic acid.

\begin{tabular}{lccc}
\hline Element & ppm & Element & ppm \\
\hline Magnesium & 2000 & Copper & 4.0 \\
Potassium & 1000 & Selenium & 1.0 \\
Iron & 1000 & Cobalt & 0.9 \\
Calcium & 300 & Zinc & 0.8 \\
Manganese & 34 & Chromium & 0.3 \\
Phosphorus & 30 & Iodine & 0.1 \\
\hline
\end{tabular}

\section{Thermoregulatory parameters:}

Temperature degrees of hair at top surface (HT), skin (ST), rectum (RT), scrotum (SCT) and top surface of ear (ET), as a physiological response, were biweekly recorded at 13:00-14:00 $\mathrm{h}$, then average values were calculated for each buck during the experimental months. The degree of RT was measured by insertion of electronic thermometer probe into the rectum to the depth of 5-6 cm. Degrees of HT, ST, ET and SCT were measured by alcohol thermometer. Both pulse rate (number of pulses/min) and respiration rate (number of breaths/min) were measured at the same time of temperature estimation.

Body and testicular measurements:

Live body weight of bucks (LBW) determined morning before feeding $1^{\text {st }}$ April (pre-treatment), $1^{\text {st }}$ May, $1^{\text {st }}$ Jun (end of treatment), $1^{\text {st }}$ July, $1^{\text {st }}$ August and end of August (end of experimental period). Body length (from top of neck to top of tail), body depth (from back surface to abdominal surface at the median region), chest circumference, and ear length were determined pre-treatment (initial) and at the end of experiment (final). At the same times, scrotal circumference, and testicular length and volume were measured according to Oberst et al. (2011).

\section{Reaction time:}

It was determined as the duration (second) elapsed from introducing each buck to doe teaser for semen collection by artificial vagina up to complete ejaculation. Reaction time was measured weekly for 13 weeks, then average of each buck was calculated during the collection period of semen.

\section{Blood samples:}

At end of the experimental period, blood samples were taken from buck jugular vein into clean test tubes contained heparin for preventing clotting (anticoagulant), then centrifuged at $3000 \mathrm{~g}$ for $20 \mathrm{~min}$, and blood plasma was stored frozen $\left(-20^{\circ} \mathrm{C}\right)$ for late assay of biochemicals. The radioimmunoassay (RIA) technique was used for determination of plasma testosterone concentration by the 
coated tubes kits (Diagnostic Products Corporation, Los Angeles, CA, USA).

\section{Statistical analysis:}

The obtained data were statistically analyzed using ANOVA procedure (SAS, 2004) to study the effect of HTs treatment on different parameters studied (One way ANOVA). The significant effect of HTs treatment was set by Duncan's multiple Range test procedure (Duncan, 1955) to clear the group differences. The obtained percentages were transferred to arc-sign pre-statistical analysis, and then the true values were tabulated as means.

\section{RESULTS AND DISCUSSION}

Results

\section{THI values of the experimental period:}

According to equation of Marai et al. (2000), values of surrounding ambient air temperature (AT), relative humidity $(\mathrm{RH} \%)$ and calculated temperaturehumidity index (THI) illustrated in figure (1) indicated very severe heat stress condition for all experimental groups during Jun-August period.

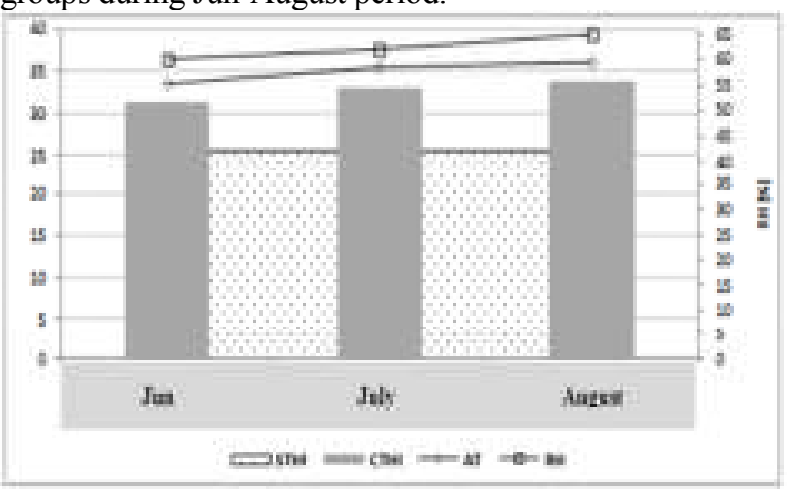

Fig. 1. Monthly air temperatures $\left(\mathrm{AT},{ }^{\circ} \mathrm{C}\right)$, relative humidity (RH, \%), very severe (STHI) and calculated (CTHI) temperature-humidity index during different summer months. (THI: based on maximum AT and RH)

Thermoregulatory and physiological response:

Results in Table 3 showed that HTs treatment significantly $(\mathrm{P}<0.05)$ reduced rectal $(\mathrm{RT})$ and scrotal (SCT) temperatures, and respiration and pulse rates compared with control. However, HTs treatment had insignificant effect on hair (HT), skin (ST) and ear (ET) temperature degrees. These results indicated positive physiological response of bucks in treatment groups, particularly those in G3, to heat stress condition as affected by HTs administration.

Table 3. Body temperature degrees, respiration rate and pulse rate during the experimental period of bucks in different groups.

\begin{tabular}{lcccc}
\hline Item & G1 & G2 & G3 & SEM \\
\hline \multicolumn{4}{c}{ Temperature $\left({ }^{\circ} \mathrm{C}\right):$} \\
Hair & 37.31 & 36.99 & 36.93 & 0.242 \\
Skin & 37.77 & 37.55 & 37.38 & 0.211 \\
Rectum & $39.83^{\mathrm{a}}$ & $39.06^{\mathrm{b}}$ & $38.87^{\mathrm{b}}$ & 0.180 \\
Scrotum & $31.68^{\mathrm{a}}$ & $30.29^{\mathrm{b}}$ & $30.86^{\mathrm{b}}$ & 0.154 \\
Ear & 36.08 & 35.63 & 35.73 & 0.240 \\
\hline
\end{tabular}

$\begin{array}{lllll}\text { Pulsation rate (p/min) } & 98.40^{\mathrm{a}} & 94.20^{\mathrm{b}} & 93.40^{\mathrm{b}} & 1.453\end{array}$ \begin{tabular}{lllll} 
Respiration rate breath/min) & $111.00^{\mathrm{a}}$ & $104.60^{\mathrm{b}}$ & $101.40^{\mathrm{b}}$ & 2.247 \\
\hline
\end{tabular} ${ }_{\text {a and }}$ : Significantly different at $P<0.05$. G1: Control.

G2: $50 \mathrm{mg} \mathrm{HTs} / \mathrm{kg}$. G3: $100 \mathrm{mg} \mathrm{HTs} / \mathrm{kg}$.
Internal and external thermal gradients:

Results in Table 4 revealed that the effect of HTs treatment on all internal gradients (ST-HT, RT-SCT and ST-SCT) was not significant. However, internal gradients between RT-ST significantly $(\mathrm{P}<0.05)$ decreased in $\mathrm{G} 2$ and G3 compared with G1. On the other hand, the external gradient between each of HT-AT, ET-AT and RT-AT significantly $(\mathrm{P}<0.05)$ decreased in treatment groups as compared to control one, but the effect of HTs o gradient between ST-AT was not significant.

Table 4. Internal gradient between body temperature degrees and external gradient between body temperature degrees and ambient temperature of bucks in experimental groups.

\begin{tabular}{lcccc}
\hline Item & G1 & G2 & G3 & SEM \\
\hline \multicolumn{5}{c}{ Internal gradient $\left({ }^{\circ} \mathrm{C}\right):$} \\
RT-ST & $2.07^{\mathrm{a}}$ & $1.51^{\mathrm{b}}$ & $1.49^{\mathrm{b}}$ & 0.153 \\
ST-HT & 0.45 & 0.56 & 0.45 & 0.051 \\
RT-SCT & 8.15 & 8.78 & 8.01 & 0.152 \\
ST-SCT & 6.09 & 7.27 & 7.52 & 0.268 \\
\hline \multicolumn{5}{c}{ External gradient $\left({ }^{\circ} \mathrm{C}\right):$} \\
HT-AT & $2.28^{\mathrm{a}}$ & $1.95^{\mathrm{b}}$ & $1.89^{\mathrm{b}}$ & 0.180 \\
ET-AT & $1.05^{\mathrm{a}}$ & $0.59^{\mathrm{b}}$ & $0.70^{\mathrm{b}}$ & 0.114 \\
ST-AT & 2.73 & 2.51 & 2.35 & 0.162 \\
RT-AT & $4.80^{\mathrm{a}}$ & $4.03^{\mathrm{b}}$ & $3.83^{\mathrm{b}}$ & 0.241 \\
\hline
\end{tabular}

a and b: Significantly different at $P<0.05$. G1: Control.

G2: $50 \mathrm{mg} \mathrm{HTs} / \mathrm{kg}$. G3: $100 \mathrm{mg}$ HTs/kg.

Body weight and measurements:

Results illustrated in figure (2) indicated slight differences in bucks weights between groups from April up to $1^{\text {st }}$ Jun, then bucks in G2 were significantly $(\mathrm{P}<0.05)$ heavier than those in G1 and G3 during July and August. These results indicated impact of HTs treatment on growth performance of bucks in $\mathrm{G} 2$, being obvious during very sever heat stress months during semen collection period.

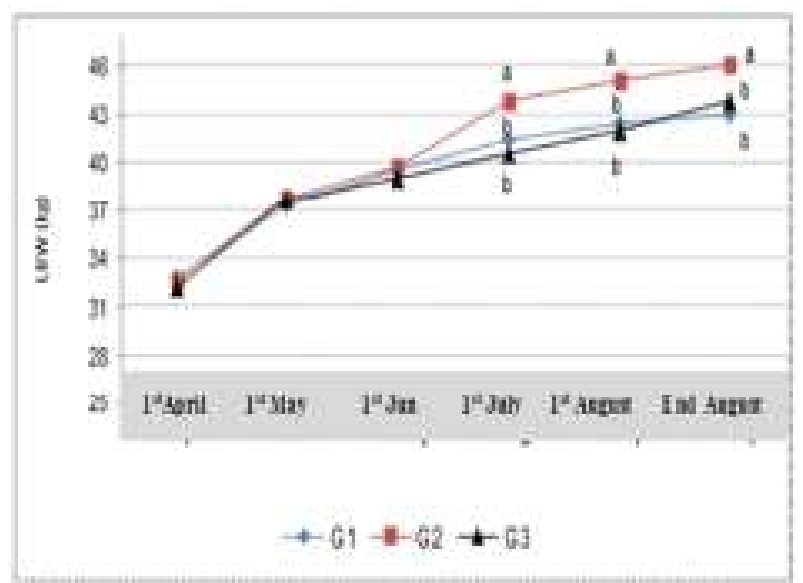

Fig. 2. Change in live body weight of bucks in G1 (control), G2 (treated with $50 \mathrm{mg}$ HTs/kg b.w.) and G3 (treated with $100 \mathrm{mg}$ HTs/kg b.w.) during different experimental months.

In association with changes in LBW of bucks, results in Table (5) indicated insignificant effect of HTs treatment on body measurements, including length, depth, chest circumference and ear length during the experimental period. 
Table 5. Change in body measurements of bucks in different experimental groups during the experimental period.

\begin{tabular}{lccccc}
\hline Measure (cm) & Period* & G1 & G2 & G3 & SEM \\
\hline \multirow{2}{*}{ Body length } & Initial & 64.20 & 65.00 & 64.80 & 0.812 \\
& Final & 71.00 & 73.40 & 75.20 & 1.751 \\
\hline \multirow{2}{*}{ Body depth } & Initial & 68.60 & 67.20 & 70.00 & 2.032 \\
& Final & 80.10 & 81.70 & 84.50 & 1.788 \\
\hline \multirow{2}{*}{ Chest circumference } & Initial & 78.60 & 80.20 & 80.80 & 2.552 \\
& Final & 80.80 & 83.60 & 84.80 & 1.736 \\
\hline \multirow{2}{*}{ Ear length } & Initial & 32.60 & 33.10 & 33.30 & 1.776 \\
& Final & 32.80 & 33.35 & 33.60 & 1.842 \\
\hline
\end{tabular}

* First April to end of September. G1: Control. G2: 50 mg HTs $/ \mathrm{kg}$ G3: $100 \mathrm{mg} \mathrm{HTs} / \mathrm{kg}$.

\section{Sexual desire:}

The effect of HTs on testicular volume and scrotal circumference was not significant, but only testes were significantly $(\mathrm{P}<0.05)$ longer in $\mathrm{G} 2$ and $\mathrm{G} 3$ than in $\mathrm{G} 1$. On the other hand, there was significant $(\mathrm{P}<0.05)$ increase in testosterone concentration, in association with significant $(\mathrm{P}<0.05)$ reduction in reaction time in $\mathrm{G} 2$ and $\mathrm{G} 3$ in comparing with G1.

Table 6. Testicular and scrotal measurements, reaction time and plasma testosterone concentration of goat bucks in experimental groups.

\begin{tabular}{lcccc}
\hline Trait & G1 & G2 & G3 & SEM \\
\hline Testicular length $(\mathrm{cm})$ & $7.30^{\mathrm{b}}$ & $8.10^{\mathrm{a}}$ & $8.10^{\mathrm{a}}$ & 0.247 \\
Testicular volume $(\mathrm{ml})$ & 64.0 & 80.0 & 86.0 & 8.236 \\
Scrotal circumference $(\mathrm{cm})$ & 21.8 & 21.6 & 20.6 & 0.874 \\
Reaction time $(\mathrm{s})$ & $240^{\mathrm{a}}$ & $164^{\mathrm{b}}$ & $138^{\mathrm{b}}$ & 13.18 \\
Testosterone $(\mathrm{ng} / \mathrm{ml})$ & $3.04^{\mathrm{b}}$ & $4.50^{\mathrm{a}}$ & $4.98^{\mathrm{a}}$ & 0.264 \\
\hline
\end{tabular}

a and b: Significantly different at $\mathbf{P}<0.05$. G1: Control. G2: $50 \mathrm{mg}$ HTs/kg. G3: $100 \mathrm{mg} \mathrm{HTs} / \mathrm{kg}$.

\section{Semen quality and sperm output:}

Treatment of HTs reflected significant $(\mathrm{P}<0.05)$ impact of both HTs treatments (G2 and G3) on increasing goat bucks to improve all characteristic of semen and sperm outputs under heat stress condition (Table 7).

Table 7. Physical semen characteristics and sperm outputs in ejaculate of goat bucks in different experimental groups.

\begin{tabular}{lcccc}
\hline Semen characteristics & G1 & G2 & G3 & SEM \\
\hline Ejaculate semen volume (ml) & 0.56 & 0.76 & 0.72 & 0.128 \\
pH value of semen & 7.74 & 7.54 & 7.44 & 0.079 \\
Mass motility (score 0-4) & 3.40 & 3.60 & 3.60 & 0.182 \\
Progressive motility (\%) & $62.00^{\mathrm{b}}$ & $66.00^{\mathrm{ab}}$ & $68.00^{\mathrm{a}}$ & 1.828 \\
Live sperm (\%) & $68.20^{\mathrm{c}}$ & $72.60^{\mathrm{b}}$ & $74.80^{\mathrm{a}}$ & 1.001 \\
Abnormal sperm (\%) & $19.00^{\mathrm{a}}$ & $16.40^{\mathrm{b}}$ & $14.20^{\mathrm{c}}$ & 0.884 \\
Acrosomal damage (\%) & $20.40^{\mathrm{a}}$ & $18.60^{\mathrm{b}}$ & $18.00^{\mathrm{b}}$ & 0.528 \\
Sperm concentration $\left(10^{6} / \mathrm{ml}\right)$ & 2.21 & 2.36 & 2.60 & 0.168 \\
\hline \multicolumn{5}{c}{ Sperm outputs $\left(10^{6} /\right.$ ejaculate): $^{\mathrm{y}}$} \\
Total & $1.24^{\mathrm{b}}$ & $1.80^{\mathrm{a}}$ & $1.90^{\mathrm{a}}$ & 0.186 \\
Motile & $0.77^{\mathrm{b}}$ & $1.21^{\mathrm{a}}$ & $1.33^{\mathrm{a}}$ & 0.151 \\
Live & $0.85^{\mathrm{b}}$ & $1.33^{\mathrm{a}}$ & $1.47^{\mathrm{a}}$ & 0.166 \\
Normal & $1.04^{\mathrm{b}}$ & $1.51^{\mathrm{a}}$ & $1.63^{\mathrm{a}}$ & 0.156
\end{tabular}

a, $b$ and c: Significantly different at $P<0.05$. G1: Control. G2: $50 \mathrm{mg}$ HTs/kg. G3: $100 \mathrm{mg} \mathrm{HTs/kg.}$

The present results suggested that humates (humic and fulvic acids mixture) has beneficial impact on body heat regulation and may improve productivity of heat stressed goat bucks. According to the obtained results, bucks in G3 receiving orally dose of $100 \mathrm{mg}$ humic and fulvic acids mixture $/ \mathrm{kg} \mathrm{LBW}$ in hot months of summer season showed the highest thermal regulation, maintained high growth performance and exhibited the best semen quality.

\section{Discussion}

Heat stress is defined as a stress inflicted by a wide range of environmental conditions that induce a state of physiological strain within an animal's body. Heat stressed animals are not able to regulate their heat homeostasis passively (Willmer et al., 2000). Previous reviews have established that heat load has a considerable impact on the productivity and welfare of livestock (Silanikove 2000a and b; Lowe et al. 2002). High ambient temperature has potentially several physiological adverse effects, including reproductive function aberration, oxidative stress, dysfunction of enzyme activity, imbalances of electrolyte, endocrine imbalance and decreasing feed intake (Kadim et al., 2008)

Climatic factors, including AT, RH and calculated THI (Marai et al., 2000) presented in figure (1) indicated that all experimental groups of bucks were exposed to very severe heat stress condition during the experimental months (Jun-August). Goats are homeotherms, and can maintain near constant RT under a wide range of environmental conditions (Morrison, 1983). The thermal comfortable zone of goats is about $12-24^{\circ} \mathrm{C}$ in the hot climates of the world (Hammadi et al., 2012).

Physiological response, in terms of RT, RR and PR are good indicators to heat stress (Helal et al., 2010), and consequently comfortable level of the animals. Changes in RT, RR and/or PR have been frequently used as indices of physiological adaptability to heat stress in small ruminants (Adedeji, 2012). Increasing animal body temperature and $\mathrm{RR}$ are the most important parameters for heat stress in goats (Alam et al., 2011). In our study, climatic conditions of hot months from Jun to September led to body thermoregulation disturbances, yielding marked elevation $(\mathrm{P}<0.05)$ in $\mathrm{RT}, \mathrm{SCT}, \mathrm{PR}$ and $\mathrm{RR}$ in control bucks in comparing with treated bucks. This finding may be considered as a strong response of control bucks for storing heat in their bodies in more pattern than in treated bucks, leading to increasing RT and RR and a deleterious effect on animal physiological status (West, 2003). Therefore, the observed low PR and RR in treated groups, particularly, in G3 may be due to higher respiration efficiency by increasing the depth of air changing rather than increasing their number (Kobeisy, 1997). It is of interest to note that ET insignificantly decreased in treatment groups as compared to control one. In this respect, Johnson et al. (1957) observed that the elevation of temperature will activate the respiratory rate about 1.5 and 2.5 times at $25^{\circ} \mathrm{C}$ and $33^{\circ} \mathrm{C}$, respectively and the dilation of veins of the ear, which is in accordance with the obtained results of the control groups in the present study. In goats, the basal referenced RR ranged (15-30 breaths/min) as reported by Robertshaw and Dmiel (1983). Thus, recording $\mathrm{RR}$ and deciding if an animal is panting, and qualifying the severity of heat stress according to panting rate (low 40 to 60 , medium 60 to 80 , high 80 to 120 , and severe $>200$ ) consider to be the most accessible and easiest method for evaluating the impact of heat stress on goats under hot condition (Silanikove, 1992; 2000b). Increased RR under heat stress was reported in goats with breaths/min up to 162 (Facanha et al., 2012). According to 


\section{J. Animal and Poultry Prod., Mansoura Univ., Vol. 10 (5), May, 2019}

these findings, goat bucks in all experimental groups showed high RR (101.4-111.0). However, there was significantly $(\mathrm{P}<0.05)$ higher increase in $R R$ in control group as compared to treated groups, especially in G3, which was mainly due to environmental conditions of heat stress (Silanikove, 2000b). Practically, increasing RR is a reliable indicator of heat load and heat stress (Okoruwa, 2014; Silanikove, 2000b). Increased RR in control bucks was an attempt to enhance heat loss by evaporation, which is considered as the highest way of heat loss in heat stressed animals (Devendra, 1987). Also, this increase may indicate animal efforts for maintaining the normal body temperature by elevation dissipation of body heat via evaporation of respiration (Hamzaoui et al., 2013).

The PR can be rapidly altered in accordance with the animal biological activity and/or by the change in environmental temperature. The normal range of PR in goats is $90-95$ beat $/ \mathrm{min}$ as reported by Heath and Olusanya (1985) and 74-91 beat/min in heat stressed goats (Alam et al., 2011; Okoruwa, 2014). Our PR results (93.4 to 98.4 beat/min) in all groups were significantly $(\mathrm{P}<0.05)$ higher in G1 than in G3, indicating that PR increased under heat stress conditions, but with less extend in treatment groups, especially in G3. Adedeji (2012) reported that high PR means increasing in blood flow from the core to the surface to give a chance for more heat dissipation by conduction, convention and radiation (sensible means) and diffusion water from the skin (insensible means).

The RT represents the resultant of all heat balance (gain and loss processes) in the animal body. It is a vital measure of heat tolerance in animals and a good index of body temperature even though there is a considerable variation in different parts of the body core at different day times. In agreement with the present results (Table 4), Devendra (1987) found an elevated RT with high environmental temperature in several studies on goats. Maintenance of body temperature is under neuronal control (Fecteau and White, 2014), sensitive neurons of temperature (warm and cold) and body temperature sensors in the skin and deep tissues (Robinson, 2002). Mammalians as homeotherms tend to maintain stable body temperature through balancing heat gain and heat loss. In goats, range of RT is $39.2-39.8^{\circ} \mathrm{C}$ (Fasoro, 1999). Heat stress increased RT of goats up to $41^{\circ} \mathrm{C}$ (Okoruwa, 2014) in relation with ambient temperature. Accordingly, in our study, RT reached $39.93{ }^{\circ} \mathrm{C}$ in G1 in comparing with 39.06 and $38.87{ }^{\circ} \mathrm{C}$ in $\mathrm{G} 2$ and $\mathrm{G} 3$, respectively. In contrast, Facanha et al. (2012) found no changes in RT in goats exposed to heat treatments. In animal body, exchange of heat from the core and its environment was controlled by the behavioral responses in term of decreasing heat gain (radiation) and increasing heat loss (convection and conduction) (Hafez, 1968). Although, Bligh (1985) stated that the increase in RR under heat stress may not be parallel with increasing RT and PR, the present results indicated good relationship between RT and both RR and $\mathrm{PR}$ in control and treatment groups, being within the normal range of RT in goats (Fasoro, 1999). In this respect, Al-Tamimi (2007) reported higher values of RR, RT, PR than that of values in thermo-neutral zone.

Under heat stress, an imbalance between heat gain and heat dissipation occurs in animals. Balancing between heat loss and heat gain or heat production enable animal for maintaining the body temperature within the normal range (Al-Dawood, 2015). In this case, animal try to adjust body temperature by increasing heat dissipation to the environment and decreasing metabolic heat production. In animals exposed to heat stress, feed intake and utilization decrease, imbalances in body water, protein, energy and minerals, enzyme activity, hormonal secretion and metabolism, reducing the loss of feces and urine and an increase sweating rate, RR (panting) and PR (Silanikove, 2000a). Goats exposed to high ambient temperature increase excess body heat dissipation to negate the excessive heat loading by mean of water evaporation from the respiratory system via panting and skin surface by sweating. In all experimental groups, ST-AT gradient was nearly similar, indicating a decrease of sensible heat dissipation. This was attributed to that ambient temperature approaches skin temperature (Caulfield et al., 2014). However, reducing HT-AT, ET-AT and RT-AT gradients significantly $(\mathrm{P}<0.05)$ in treatment groups as compared to control one may indicate higher heat loss by dissipation from hair, ear and core to environment as affected by HTs treatment. In addition, there is recruitment of evaporative processes, primarily sweating and less increased respiration rate (Mortola and Frappell, 2000) in treatment groups.

Under the normal condition, RT is nearly constant (Silanikove, 2000a) and a rise of $\geq 1$ degree in in RT in most livestock species, may be enough to decrease animal performance (Shebaita and El-Banna, 1982), leading to decreasing body weight and gain in heat stressed goats (Okoruwa, 2014). Increasing body weight gain during heat stress in bucks of G2 might be attributed to reduction in energy expended for heat dissipation through respiratory evaporation (RR), and subsequently increasing water availability during heat stress as compared to bucks G1 and G3 (Okoruwa, 2014). Similarly, growth performance of growing heat stressed rabbits improved $(\mathrm{P}<0.05)$ by dietary supplementation of betaine (Hassan et al., 2009). Increasing body weight of bucks treated with HTs may be attributed to effect of HTs on stabilizing the microflora in the intestine, leading to improvement in nutrient utilization of animal feeds. This finding was proved in laying hens (Shermer et al., 1998).

In AI programs, sexual desire is important for evaluating reproductive capacity of males and it depends on blood testosterone concentration (Abdel-Rahman and Kandil, 1984). Intensity of sexual libido depends on peripheral androgen concentration, which is directly effect on the sexual behavior and fertility of bucks in temperate regions. Studies of sexual desire on goat bucks in relation to season of the year showed contradictory results. Freitas and Nunes (1992) reported that season had no effect on sexual libido. Males of tropical origin display their sexual activity all the year round (Chemineau, 1986), although, wide fluctuation in testosterone and sexual behavior had been found in temperature climate during or out the breeding season (Ahmad and Noakes, 1995). Also, Sinha et al. (1981) found that the reaction time was not influenced by season. With regard to reaction time of goat bucks, El-Wishy et al. (1971) found that reaction time of Damascus goat was 74.3, 170.85, 193.1 and $338.4 \mathrm{~s}$ in autumn, summer, winter and spring, respectively. 
Improving sexual desire of bucks in G2 and G3 may be attributed to improving testicular measurements and testosterone concentration as affected by humates treatment.

In Damascus goats, semen volume, abnormal spermatozoa, concentration of sperm cells and total outputs of spermatozoa were lower, while sperm motility was higher in summer than in winter (El-Wishy, 1971; ElSaidy, 1988), while the highest sperm livability was recorded in summer (El-Saidy, 1988). According to the obtained results, HTs treatment improved all semen characteristics of goat bucks under heat stress condition. Beside that HTs had antioxidant, anti-inflammatory, antiviral and immunity properties (Klocking, 1972; Jankowski, 1993), the mode of action of HTs to improve rumen fermentation and ruminal microbial activity was reported. In this respect, Majewska et al. (2017) suggested that humic acid stimulates the growth of fibrolytic microorganisms in the rumen and reduced the rate of carbohydrate degradation in the rumen. Therefore, impact of HTs on increasing the ability of treated goat bucks to exhibit good performance and high production better than control in harsh environments due to high digestive efficiency and utilization of high fiber forage (Silanikove and Koluman, 2015; Silanikove, 2000b). Based on the present thermoregulation in the experimental groups, the HTs treatment caused the immune system to recognize its own dead cells thereby reducing infection. "Russian scientists are using the same principle for the treatment of radiation sickness. Sodium humate has been found to increase the lifespan of mongrel rats exposed to lethal doses of cobalt radiation (Pukhova et al., 1987). Each of HA and FA or HA/FA-like substances is characterized by their ability to interact with xenobiotics to form complexes of different solubility, and chemical and biochemical stability. Therefore, HA and FA represent a strongly $\mathrm{pH}$ dependent reservoir of electron donors/acceptors, which could hypothetically contribute to reduction-oxidation of several inorganic and organic agents (Pacheco et al., 2003).

In conclusion, bucks in $\mathrm{G} 3$ receiving orally dose of $100 \mathrm{mg}$ humic and fulvic acids mixture/kg LBW in hot months of summer season showed highest thermal regulation, which maintain live body weight, improve sexual desire and semen quality under heat stress condition.

\section{REFERENCES}

A.O.A.C. (2000). Association of Official Analysis Chemists, Official Methods of Analysis. 5th Edition Washington, D.C., USA.

Abdel-Rahman, H. and Kandil, A.A. (1984). Seasonal variation in mating behaviour in male goat in association with semen characteristics. Munifyia J. Agric. Sci., 9: 257-270.

Adedeji, TA. (2012). Effect of some qualitative traits and non-genetic factors on heat tolerance attributes of extensively reared West African Dwarf (WAD) goats. Inter. J. Appl. Agric. Apicul. Res., 8:68-81.

Ahmad, N. and Noakes, D.E. (1995). Seasonal variation in testis size, libido and plasma testosterone concentration in British goats. Anim. Sci., 61: 553559.
Alam, M.M.; Hashem, M.A.; Rahman, M.M.; Hossain, M.M.; Haque, M.R.; Sobhan, Z. (2011). Effect of heat stress on behavior, physiological and blood parameters of goat. Prog. Agric., 22:37-45.

Al-Dawood, A. (2015). Adoption of agricultural innovations: Investigating current status and barriers to adoption of heat stress management in small ruminants in Jordan. Amer.-Euras. J. Agric. Environ. Sci., 15:388-398.

Al-Tamimi, H.J. (2007). Thermoregulatory response of goat kids subjected to heat stress. Small Rumin. Res., $7: 280285$.

Bligh, J. (1985). Temperature regulation. In: Stress physiology in livestock. Basic Principles, Yousef, M.K. (ed.). CRC Press Inc., Boca Raton, FL, USA. 1:75-96.

Caulfield, M.P.; Cambridge, H.; Foster, S.F.; McGreevy, P.D. (2014). Review: Heat stress: a major contributor to poor animal welfare associated with long-haul live export voyages. Vet. J. 2014; 199:223-228.

Chemineau, P. (1986). Sexual behaviour and gonadal activity during the year in the tropical creole meat goat II. Male mating behaviour, testis diameter, ejaculate characteristics and fertility. Reproduction Nutrition, Development, 26: 453.

Chirase, N.K., Greene, L.W., McCollum, F.T., Auvermann, B.W. and Cole, N.A. (2000). Effect of Bovipro on performance and serum metabolites concentrations of beef steers. Western Section, American Society of Animal Science Proceedings, 51, 415-418.

Davidson, J.N. and Farver, T.B. (1980). Conception rate of Holstein for artificial insemination on a California dairy. J. Dairy Sci. 63, 621-626.

Devendra, C. (1987). Goats. In: Bioclimatology and the adaptation of livestock, Johnson H.D. (eds). Elsevier, Amsterdam, The Netherlands, 157-168.

Duncan, D.B. (1955). Multiple ranges and multiple F test. Biometrics 11: 1-42.

El-Saidy, B.E.I. (1988). Studies on reproductive physiology in male goats. M.Sc. Thesis, Fac. Agric., Mansoura Univ., Egypt.

El-Wishy, A.B.; El-Sawaf, S.A.; El-Mikkawi, F. and Omar, A.A. (1971). Monthly and seasonal variation in sexual activity of male Damascus goats. Ind. J. Anim. Sci., 41: 562-569.

Facanha, D.A.E.; Sammichelli, L.; Bozzi, R.; Silva, W.S.T.; Morais, J.H.G.; Lucena, R.M.O. (2012). Performance of Brazilian native goats submitted to a mix supply under thermal stress conditions. Proc. XI International Conference on Goats, Gran Canaria, Spain, pp 343.

Fasoro, B.F. (1999). Heat stress index in three breeds of goats. Agric. Project, Dept. of Animal Breeding and Genetics, University of Agriculture, Abeokuta, Nigeria, 6-28.

Fecteau, M.E. and White, S.L. (2014). Alteration in body temperature. In: Large animal internal medicine, Smith B.P. (ed.). Elsevier Health Sciences, $5^{\text {th }}$ ed., 3139.

Freitas, V.J.F. and Nunes J.F. (1992). Andrological semen characters in the dry and rainy seasons of wooless sheep in a coastal area North East Brazil. Revista de Reproducao Anim. 16: 95-104. 
Gherardi, P.B.; Lindsay, D.R. and Oldham, C.M. (1980). Testicle size in rams and flock fertility. Proc. Aust. Soc. Anim. Prod. 13, 48-50.

Hafez, E.S.E. (1986). Behavioral adaptation. In: Adaptation of domestic animals, Hafez E.S.E. (ed.). Lea and Febiger, Philadelphia, PA., 202-214.

Hammadi, M.; Fehem, A.; Harrabi, H.; Ayeb, N.; Khorchani, T.; Salama, A.A.K. (2012). Shading effects on respiratory rate and rectal temperature in Tunisian local goat kids during summer season. Proc. XI International Conference on Goats, Gran Canaria, Spain, pp 127.

Hamzaoui, S.; Salama, A.A.K.; Albanell, E.; Such, X. and Caja, G. (2013). Physiological responses and lactational performances of late-lactation dairy goats under heat stress conditions. J. Dairy Sci., 96:63556365 .

Hassan, R.A.; Ebied, T.A.; Abd El-Latif, A.I. and Ismail, N.B. (2009). Effect of dietary betaine supplementation on growing rabbits under heat conditions. Egyp. J. rabbit Science, 19 (2): 119-136.

Hayirl, A.; Esenbuga, N.; Macit; M. Lacin, E.; Karaoglu, M.; Karaca, H. and Yildiz, L. (2005). Nutrition practice to alleviate the adverse effects of stress on laying performance, metabolic profile, and egg quality in peak producing hens: I. The humate supplementation. Asian-Aust. J. Anim. Sci., 18: 1310-1319.

Heath, E and Olusanya, S. (1985). Anatomy and physiology of tropical livestock. Intern. Tropical Agric. Series, Longman, $3^{\text {rd }}$ ed. $\mathrm{p} 138$.

Helal, A.; Hashem, A.L.S.; Abdel-Fattah, M.S. and El-Shaer, H.M. (2010). Effects of heat stress on coat characteristics and physiological responses of Balady and Damascus goats in Sinai, Egypt. Amer.-Euras. J Agric. Environ. Sci., 7:60-69.

Jankowski, A. (1993). A randomized blind study on the efficacy of Tolpa Torf preparation in the treatment of recurring respiratory tract infections. Arch Immunol Ther Exp, Vol. 41; Issue 1; pages 95-97.

Johnson, H.D., Ragasdale, A.C. and Eheng, C.S. (1957). Influence of constant environmental temperatures on growth responses and physiological reactions of rabbits and cattle. Mo. Agric. Exp. Sta. Res. Bull. No 648.

Kadim, I.T.; Mahgoub, O.; Al-Marzooqi, W.; Al-Ajmi, D.S.; Al-Maqbali, R.S. and Al-Lawati, S.M. (2008). The influence of seasonal temperatures on meat quality characteristics of hot-boned, m. psoas major and minor, from goats and sheep. Meat Sci., 80:210-215.

Karaoglu, M.; Macit, M.; Esenbuga, N.; Durdag, H.; Turgut, L. and Bilgin, O.C. (2004). Effect of Supplemental Humate at Different Levels on the GrowthPerformance, Slaughter and Carcass Traits of Broilers. Int. J. Poult. Sci., 3: 406-410.

Klocking, R. (1972). Antiviral properties of humic acids. Experientia, Vol. 28, Issue 5, Pages 607-608.

Kobeisy S. (1997). Effect of vitamin C and E on rectal temperature and respiratory rates in heat stressed goats. Assiut. Vet. Med. J. 1997; 37:120-132.
Kocabagli, N., Alp, M.; Acar, N. and Kahraman, R. (2002).The effects of dietary humate supplementation on broiler growth and carcass yield. Poult. Sci., 81:227-230.

Livestock Poultry Heat Stress Index (1990). Livestock and Poultry Heat Stress Indices. The Heat Stress Indices for Poultry, Cattle, Sheep and Goats. The Agriculture Engineering Technology Guide, Clemson University, Clemson, SC, USA.

Lowe, T.E.; Gregory, N.G.; Fisher, A.D. and Payne, S.R. (2002). The effects of temperature and water deprivation on lamb physiology, welfare and meat quality. Australian Journal of Agricultural Research 53, 707-714.

Marai, I.F.M.; Bahgat, L.B.; Shalaby, T.H. and Abdel-Hafez, M.A. (2000). Fattening performance, some behavioral traits and physiological reactions of male lambs fed concentrates mixture alone with or without natural clay under hot summer of Egypt. Annals of Arid Zone, 39, 449- 460.

Mirnawati, Y.R. and Marida, Y. (2013). Effects of humic acid addition via drinking water on the performance of broilers fed diets containing fermented and nonfermented palm kernel cake. Arch. Zootech., 16: 4153.

Morrison, S.R. (1983). Ruminant heat stress: effect on production and means of alleviation. J Anim. Sci., 57:15941600

Mortola, J.P. and Frappell, P.B. (2000). Ventilatory responses to changes in temperature in mammals and other vertebrates. Ann. Rev. Physiol., 62:847-874.

NRC (1985). Nutrient Requirement of Sheep, 6th rev. ed. National Research Council, National Academy of Sciences. Washington DC.

Oberst, E.R.; Smirdele, W.A.; Brito, M.A.; Marschner, T.R.; Ribeiro, L.A. and Mattos, R.C. ( 2011). Seasonal variation in semen quality of Lacaune rams in Brazil. Brazilian Journal of Veterinary Research and Animal Science, 48: 319-324.

Okoruwa, M.I. (2014). Effect of heat stress on thermoregulatory, live body weight and physiological responses of dwarf goats in southern Nigeria. Europ. Sci. J., 10:255-264.

Pacheco, MX., Pena-Mendez, E.M. and Havel, J. (2003). Supramolecular interactions of humic acids with organic and inorganic xenobiotics studied by capillary electrophoresis. Chemosphere 51(2), 95-108.

Pukhova, G.G.; Druzhina, H.A.; Stepchenko, L.M.; Chebotarev, E.E. (1987). Effect of sodium humate on animals irradiated with lethal doses. Radiobiologiia, Vol. 27; Issue 5; Pages 650-653.

Rege, J.E.O.; Toe, F.; Mukasa-Mugerwa, E.; Tembely, S.; Anindo, D.; Baker, R.L. and Lahlou-Kassi, A. (2000). Reproductive characteristics of Ethiopian highland sheep. II: Genetic parameters of semen characteristics and their relationships with testicular measurements in ram lambs. Small Rumin. Res. 37, 173-187.

Robertshaw, D. and Dmiel, R. (1983). The effect of dehydration on the control of panting and sweating in the black Bedouin goat. Physiol. Zool., 56:412-418. 
Robinson, N.E. (2002). Thermoregulation. In: Textbook of veterinary physiology, Cunningham J.G. (ed.). WB Saunders, Philadelphia, pp 533-542.

SAS (2004). Statistical Analysis System, SAS User's Guide Statistics, SAS Institute Inc., Editions Cary NC, USA.

Shebaita, M.K. and El-Banna, I.M. (1982). Heat load and heat dissipation in sheep and goats under environmental heat stress. Proc. VI International Conference on Animal and Poultry Production, University of Zagazig, Zagazig, Egypt, 459-469.

Shermer, C. L.; Maciorowski, K. G.; Bailey, C.A.; Byers, F.M.; Ricke, S.C. (1998). Caecal metaboliies and microbial populations in chickens consuming diets containing a mined humate compound. Journal of the science of food and agriculture, Vol. 77; Issue 4, Pages 479-486.

Shi, Y.; David, B.; Parker, N.; Andy, C. and Joey, A. (2001). Mehlhorn.Surface amendments to minimize ammonia emissions from beef cattle feedlots. Amer. Socie. Agric. Eng. 44(3): 677-682.

Silanikove, N. (2000a). Effects of heat stress on the welfare of extensively managed domestic ruminants. Livest. Prod. Sci., 67:1-18.

Silanikove, N. (2000b). The physiological basis of adaptation in goats to harsh environments. Small Rumin. Res., $35: 181-193$.
Silanikove, N. (1992). Effects of water scarcity and hot environment on appetite and digestion in ruminants: A review. Livest. Prod. Sci., 30:175-194.

Silanikove, N. and Koluman, N. (2015). Impact of climate change on the dairy industry in temperate zones: predications on the overall negative impact and on the positive role of dairy goats in adaptation to earth warming. Small Rumin. Res., 123:27-34.

Sinha, N.K.; Wani, G.M. and Sahni, K.L. (1981). Effect of season and age on seminal attributes of Jamnapari bucks. Ind. Vet. J., 58: 963.

Stevenson, F.J. (1982). Humus Chemistry: Genesis, Composition, Reactions. $1^{\text {st }}$ ed. Wiley. New York, USA.

Syrstad, O. (1981). Selection for fertility on the basis of AI data. Livest. Prod. Sci. 8, 247-252.

Taklimi, S.M.S.M., Ghahri, H. and Isakan, M.A. (2012). Influence of different levels of humic acid and esterified glucomannan on growth performance and intestinal morphology of broiler chickens. Agr. Sci., 3: 663-668.

West, J.W. (2003). Effects of Heat-Stress on Production in Dairy Cattle. J. Dairy Sci. 86:2131-2144.

Willmer, P.; Stone, G. and Johnston, J. (2000). Environmental physiology of animals. $1^{\text {st }}$ ed. Blackwell Scientific Publications, Oxford. 672 pp.

\section{تأثير المعامله بخليط من حمض الاباليه الهيوميك وحض الفلفيك الفولفيك على الآداء الأنتاجى والتناسلى لتيوس

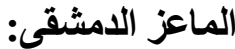

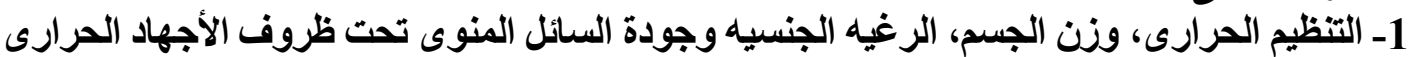

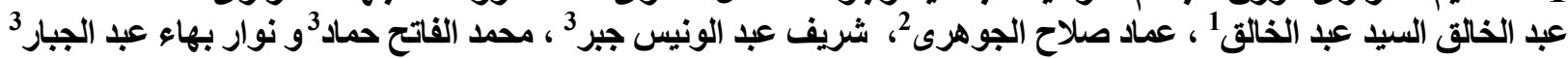

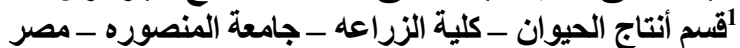

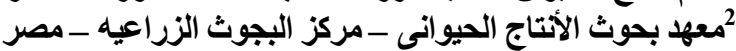

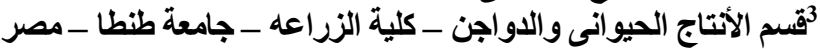

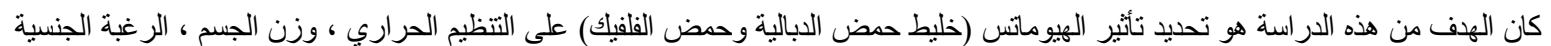

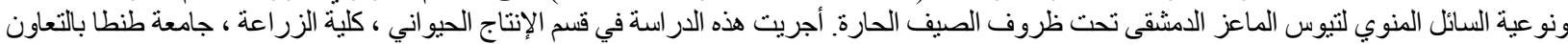

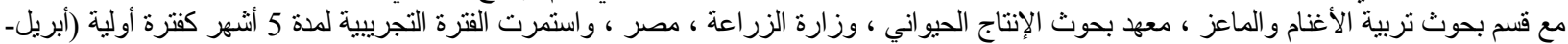

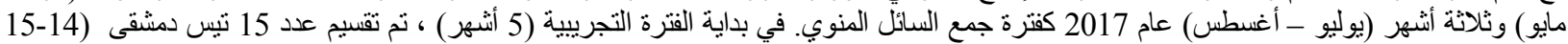

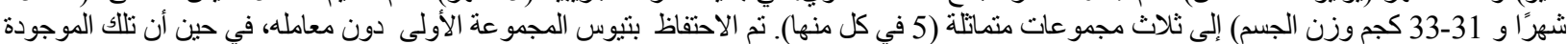

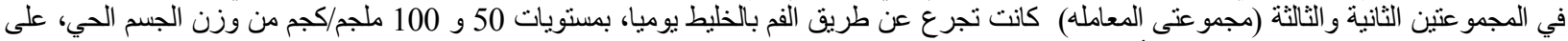

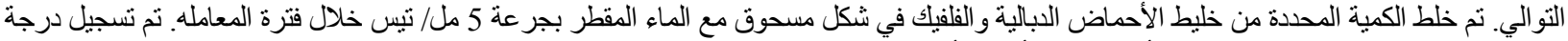

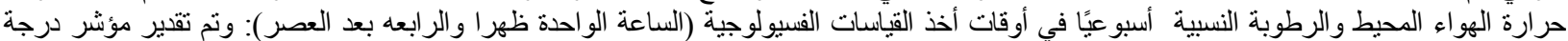

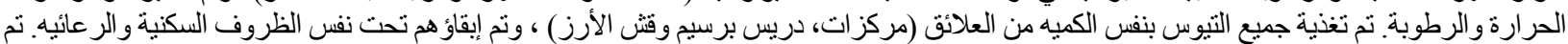

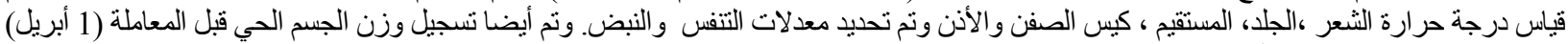

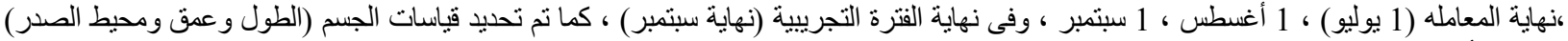

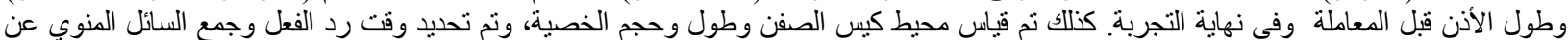

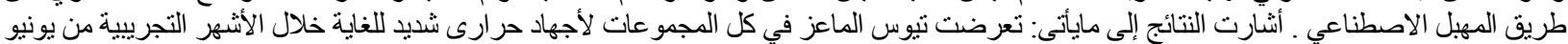

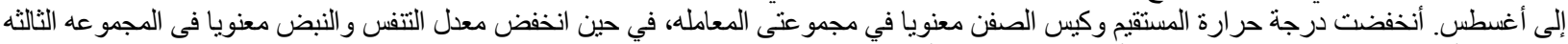

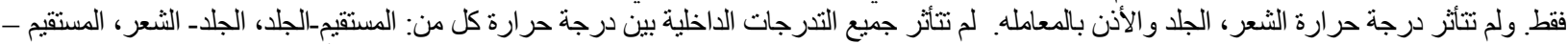

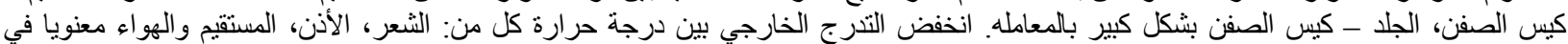

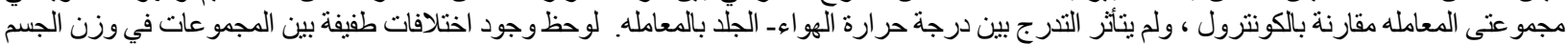

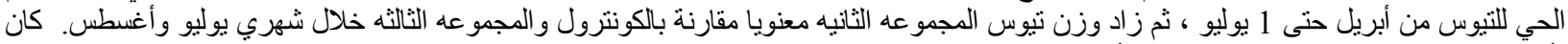

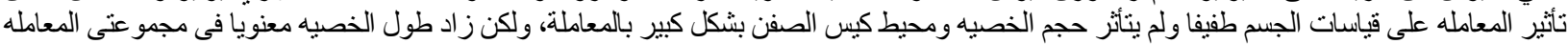

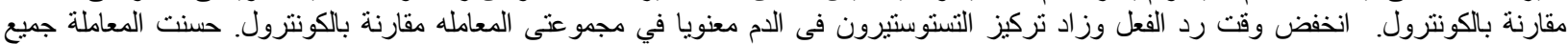

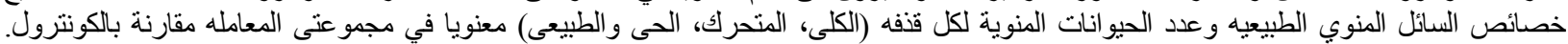

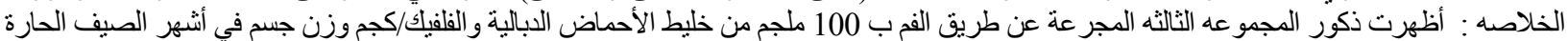
أعلى تتظيم حراري مما ساعده على المحافظه على وزنهاوتحسين الرغبه الجنسيه و أظهار أفضل نوعية للسائل المنوي خلال فترة الأجهاد الحرارى. 